\title{
CONSILIUM
}

Berkala Kajian Konseling Dan Ilmu Keagamaan

Avalaible at http:/ /jurnal.uinsu.ac.id/index.php/consilium

ISSN : 2338-0608 (Print) | ISSN : 2654-878X (Online)

\section{Hubungan Konformitas Teman Sebaya Dengan Sikap Siswa Terhadap Perilaku Prososial}

\author{
Oleh: \\ Nur Hafiza
}

Program Studi S2 Bimbingan dan Konseling, Fakultas Ilmu Pendidikan, UNP Padang, Indonesia. Jl. Prof. Hamka, Air Tawar, Padang, Sumatera Barat. Korespondensi:

nurhafiza.fz@gmail.com

\begin{abstract}
The depletion of students' prosocial behavior is one of the problems related to how students understand about prosocial behavior, what they feel when they see the difficulties of others and what tendencies will arise when they are prosocial. The purpose of this study is to reveal the relationship between peer conformity and students' attitudes towards prosocial behavior. This research uses a quantitative method with a descriptive correlational type. The population was 322 students, and the sample was 62 students selected by proportionate stratified random sampling technique. The instrument is peer conformity and student attitudes toward the scale of prosocial behavior. Data were analyzed with descriptive statistics, simple regression and multiple regression. The results showed that the performance of students' peers was in the high category, and students' attitudes toward prosocial behavior were in a good category, there was a positive and significant relationship between peer conformity and students' attitudes toward prosocial behavior. The implications of this research can be made as an assessment of students' needs to create guidance and counseling services..
\end{abstract}

Keywords: Religiosity, Peer Conformity, Student Attitudes, Prosocial Behavior

\section{PENDAHULUAN}

$\square$ iswa memperlihatkan sikap dan perilaku mereka masing-masing serta saling mempengaruhi satu sama lain dalam berinteraksi dengan individu lain. Interaksi sosial yang terjadi ada yang bersifat menguntungkan, seperti bekerja sama, bergotong royong, dan saling tolong menolong. Dalam konteks kehidupan sehari-hari, perilaku prososial sangat luas cakupannya. Perilaku prososial tidak hanya memberikan bantuan terhadap korban bencana alam saja, namun juga dapat terjadi dalam aktifitas siswa sehari-hari yang dapat meringankan beban orang lain, seperti ikut serta dalam membersihkan kelas, menolong teman yang membutuhkan bantuan, bersikap jujur dan adil dalam bertingkah laku, tidak mencela teman yang memiliki kekurangan, bersikap sopan kepada guru, dan lain sebagainya. 
Permasalahannya adalah bahwa kecenderungan siswa untuk melakukan perilaku prososial mulai menurun dan jarang ditemui. Pada perkembangan saat ini diberbagai tempat bahkan di sekolah tidak sedikit ditemui perilaku siswa yang jauh dari perilaku prososial seperti siswa lebih bersifat individual atau mementingkan kepentingan dirinya sendiri. Siswa banyak yang menganut gaya hidup hedonis, yang membuat mereka hanya berpikir tentang kesenangan diri sendiri tanpa mau memikirkan keadaan orang lain. Siswa bukannya gemar untuk melakukan perilaku prososial, justru sebaliknya malah semakin banyak di antara remaja yang melakukan perilaku antisosial.

Kecenderungan perilaku prososial yang rendah ditemui bahkan ada yang sangat rendah, sebagaimana dalam penelitian Sari (2013) skor perilaku prososial dari 10 (sepuluh) orang siswa berada pada kategori sangat rendah 2 (dua) orang siswa, kategori rendah 8 (delapan) orang siswa dan tinggi 1 (satu) orang siswa. Selain itu, penelitian yang dilakukan Putra, Gistituati, dan Syahniar (2015) diperoleh hasil yaitu secara rata-rata tingkat perilaku prososial siswa berada pada kategori rendah. Berdasarkan hasil penelitian tersebut menunjukkan kecenderungan siswa untuk melakukan perilaku prososial mulai menurun.

Penelitian Nufus (2012) menunjukkan rendahnya perilaku prososial santri, ia menemukan bahwa sebagian santri di Pesantren Nurul Ummah Kotagede, Yogyakarta semakin individualis. Beberapa kasus diantaranya adalah RU (20 tahun) yang ketika sakit terpaksa pergi berobat sendiri karena tidak ada teman yang bersedia mengantar ke dokter, kasus lainnya, AZ (16 tahun) mengaku bahwa ia cenderung menolong teman yang satu kamar dengannya., jika ada teman lain yang sakit, terkedang ia tidak mengetahuinya dengan alasan tidak terlalu dekat dengan orang tersebut. Selain itu, Andeli dan Noor (2015) dalam penelitiannya menguji hubungan religiusitas dengan perilaku prososial pada anggota relawan KORS, dan menunjukkan hasil bahwa terdapat 11 orang dari 32 orang anggota KORSA memiliki perilaku prososial yang sedang.

Banyak faktor yang mempengaruhi siswa untuk berperilaku prososial, diantaranya adalah konformitas teman sebaya. Sebagaimana yang diungkapkan Dayakisni dan Hudaniah (2009) bahwa faktor yang melatarbelakangi seseorang bersikap prososial, salah satunya yaitu personal values dan norms. Hasil penelitian Bradley, Giletta, Cohen, dan Prinstein (2015) menjelaskan bahwa efek dari pengaruh teman sebaya menunjukkan potensi internalisasi norma-norma teman yang bersikap prososial. Sehingga hal tersebut dapat membantu siswa dalam mengembangkan sikap dan perilaku yang positif dengan adanya pengaruh posotif dari teman sebaya. Gommans, Sandstrom, Stevens, Bogt dan Cilleseen (2017) mengungkapkan bahwa remaja lebih cenderung menyesuaikan diri dengan teman-teman yang berstatus sosial tinggi dibandingkan teman-teman 
yang berstatus sosial rendah. Sehingga dapat disimpulkan bahwa siswa atau remaja pada masanya mengalami proses pencarian identifikasi cenderung akan menyesuaikan sikap dan perilaku mereka dengan orang lain yang disukainya atau yang populer di lingkungannya.

Penelitian yang dilakukan Yantiek (2014) pada 3 SMA ternama di Gresik diperoleh data bahwa hampir tiap tahun sebanyak 20\% siswa di sekolah yang kurang peduli terhadap kesulitan orang lain, seperti, ketika ada salah seorang siswa yang menangis karena menerima telpon bahwa keluarganya mengalami musibah kecelakaan, tapi teman-teman disekitarnya diam saja tanpa memperdulikannya. Penelitian yang dilakukan Zhixu, Xinyuan, Xiaoxia, dan Yichen (2017) terhadap materialisme dan perilaku prososial remaja mengemukakan bahwa remaja cenderung berinteraksi dengan teman sebaya atau orang lain atas dasar materialismenya yang tinggi, yang berarti kecenderungan remaja untuk berhubungan sosial dengan temannya didasari oleh ada tidaknya manfaat baginya yang berarti bahwa masih terdapat siswa remaja yang berperilaku prososial karena mengharapkan sesuatu atau melihat apakah itu menguntungkannya atau tidak.

Fenomena yang terjadi di SMA Muhammadiyah 4 Babalan, terdapat siswa yang enggan untuk bekerjasama membantu kesulitan teman yang kurang memahami pelajaran, kurang kepedulian untuk berbagi makanan kepada teman yang terlihat tidak membeli makanan ketika jam istirahat. Selain itu, juga terdapat siswa yang bersikap tidak peduli untuk bekerjasama dalam bergotong royong membersihkan lingkungan sekolah. Berdasarkan fenomena tersebut, memperlihatkan bahwa masih terdapat siswa yang kurang peka terhadap teman sebaya dan lingkungannya, sehingga fakta di atas menegaskan bahwa perilaku prososial siswa masih rendah.

Permasalahan ini terungkap ketika peneliti melakukan studi pendahuluan melalui wawancara dengan guru BK di SMA Muhammadiyah 4 Babalan pada bulan Maret 2017, menunjukkan bahwa masih terdapat siswa yang menunjukkan sikap tidak peka untuk memberikan bantuan terhadap teman yang terlihat sering tidak makan pada jam istirahat, kurangnya kepedulian untuk datang menjenguk teman yang sakit, kurangnya kemauan siswa dalam menyumbang untuk tabungan amal yang dilakukan setiap hari jumat, kurangnya berbagi ilmu dengan teman yang membutuhkan penjelasan tentang pelajaran, memilih-milih dalam memberikan pertolongan (cenderung menolong teman yang disukai atau yang berasal dari desa yang sama), sering berbohong kepada teman maupun guru, membuang sampah tidak pada tempatnya, kurangnya kesadaran untuk berkerjasama dengan teman di kelasnya serta enggan memberikan tumpangan motor kepada teman yang berjalan kaki 
sepulang sekolah. Apabila perilaku tersebut terus dibiarkan tanpa diberikan penanganan, maka akan merugikan siswa, menghambat proses sosialisasi dengan teman sebaya dan proses belajar di sekolah.

Sikap siswa yang menerima untuk berperilaku prososial masih perlu menjadi sorotan penting bagi guru, orangtua, masyarakat bahkan diri siswa itu sendiri yang diharapkan jangan sampai diabaikan tanpa ada pemeliharaan dan pengembangannya, karena akan mengakibatkan menurunnya kondisi perilaku prososial di lingkungan sekolah. Siswa harus siap untuk menjadi pelaku prososial yang aktif, jika tidak, lingkungan juga akan memberikan timbal balik terhadap sikap dan perilaku yang telah ditampilkannya. Sehingga, hal tersebut akan menimbulkan masalah bagi kehidupannya. Masalah tidak akan lepas dari siswa sepanjang proses interaksinya dengan lingkungan.

\section{METODOLOGI}

Penelitian ini menggunakan pendekatan kuantitatif dengan jenis deskriptif korelasional. Populasi penelitian adalah seluruh siswa SMA Muhammadiyah 4 Babalan yaitu mencakup kelas X, XI dan XII yang terdaftar pada Tahun Ajaran 2016/2017 yang berjumlah 322 orang dan sampel dalam penelitian ini sebanyak 62 orang. penarikan sampel menggunakan teknik proportionate stratified random sampling. Instrumen yang digunakan adalah skala konformitas teman sebaya, dan sikap siswa terhadap perilaku prososial.

\section{HASIL PENELITIAN}

Tabel 4. Ringkasan Uji Signifikansi Hubungan Religiusitas dan Konformitas Teman Sebaya dengan Sikap Siswa terhadap Perilaku Prososial Secara Sendiri dan Bersama-sama

\begin{tabular}{|c|c|c|c|}
\hline Variabel & F $_{\text {hitung }}$ & F $_{\text {tabel }}$ & Signifikansi \\
\hline $\mathrm{X}_{2}-\mathrm{Y}$ & 21,831 & 3,99 & 0,000 \\
\hline
\end{tabular}

Berdasarkan Tabel 4 dapat ditarik kesimpulan penelitian yaitu terdapat hubungan yang signifikan antara konformitas teman sebaya dengan sikap siswa terhadap perilaku prososial. Hal ini ditunjukkan oleh Sig. 0,000 lebih kecil dari 0,05 yang berarti bahwa terdapat hubungan yang signifikan antara konformitas teman sebaya dengan sikap siswa terhadap perilaku prososial.

\section{PEMBAHASAN}




\section{Hubungan Konformitas Teman Sebaya dengan Sikap Siswa terhadap Perilaku Prososial}

Hasil penelitian memperlihatkan terdapat hubungan positif dan signifikan antara konformitas teman sebaya dengan sikap siswa terhadap perilaku prososial. Penelitian ini didukung oleh penelitian Abdullah dan Handayani (2015), yang berdasarkan hasil penelitian mengungkapkan bahwa ada hubungan yang positif dan signifikan antara variabel konformitas dengan variabel perilaku prososial. Dengan demikian, dapat dipahami bahwa munculnya kecenderungan siswa untuk berperilaku prososial dapat terjadi dengan adanya pengaruh dari teman sebaya yang membuat siswa menjadi bersikap dan berperilaku yang sama dengan teman sebaya. Akan tetapi, konformitas teman sebaya berdasarkan hasil temuan penelitian hanya sedikit mempengaruhi sikap siswa terhadap perilaku prososial.

Penelitian yang dilakukan Buhmester (dalam Santrock, 2012) menunjukkan bahwa pada masa remaja kedekatan hubungan siswa dengan teman sebaya meningkat secara drastis, dan pada saat yang bersamaan kedekatan hubungan remaja dengan orangtua menurun secara drastis. Teman sebaya atau peers adalah anak-anak dengan tingkat kematangan atau usia yang kurang lebih sama. Salah satu fungsi terpenting dari kelompok teman sebaya adalah untuk memberikan sumber informasi dan komparasi tentang dunia di luar keluarga. Melalui kelompok teman sebaya anak-anak menerima umpan balik dari teman-teman mereka tentang kemampuan mereka. Anak-anak menilai apa-apa yang mereka lakukan, apakah dia lebih baik dari pada teman-temannya, sama, ataukah lebih buruk dari apa yang anak-anak lain kerjakan. Hal demikian akan sulit dilakukan dalam keluarga karena saudara-saudara kandung biasanya lebih tua atau lebih muda (bukan sebaya) (Santrock, 2012).

\section{KESIMPULAN}

Berdasarkan temuan yang diperoleh dalam penelitian ini berdasarkan analisis statistik dan uji hipotesis serta dikaji dan dijabarkan dalam pembahasan, maka dapat disimpulkan

1. Sikap siswa terhadap perilaku prososial berada pada kategori baik. Tingkat penerimaan siswa yang diukur berdasarkan kognitif, afektif dan konatif siswa terhadap bentuk perilaku prososial sudah baik dan positif.

2. Konformitas teman sebaya siswa memiliki hubungan yang positif dan signifikan dengan sikap siswa terhadap perilaku prososial, yang berarti apabila konformitas teman sebaya siswa meningkat, maka sikap siswa terhadap perilaku prososial akan menjadi meningkat juga, dan sebaliknya.

\section{DAFTAR RUJUKAN}


Abdullah, A. \& Handayani, S. W. R. I. (2015). Hubungan Konformitas dan Perilaku Prosoial pada Pedagang Kaki Lima Pasar Besar Malang. Jurnal Psikovidya, 19(1), P-ISSN: 0853-8050, E-ISSN: 2502-6925.

Ayudhia, R. R. \& Kristiana, I. F. (2016). Hubungan antara Hardiness dengan Perilaku Prososial pada Siswa Kelas XI SMA Islam Hidayatullah Semarang. Jurnal Empati, 5(2), 205-210.

Azwar, S. (2011). Sikap Manusia: Teori dan Pengukurannya. Yogyakarta: Pustaka Pelajar.

Bradley, S. C., Giletta, M., Cohen, G. L., dan Prinstein, M. J. (2015). Peer Influence, Peer Status, and Prosocial Behavior: An Experimental Investigation of Peer Socialization of Adolescents' Intentions to Volunteer. Journal of Youth and Adolescence, 22(12), 2197-2210.

Daniprawiro, M. (2009). Menipisnya Budaya Tradisional. Gemari. Edisi 96/Tahun IX/Januari 2009, 78-79.

Dayakisni, T. \& Hudaniah. (2003). Psikologi Sosial. Malang: UMM Press.

Desmita. (2015). Psikologi Perkembangan Peserta Didik. Bandung: Remaja Rosdakarya.

Eisenberg, N. \& Mussen, P. H. (2003). The Roots of Prosocial Behavior in Children. Cambridge: Cambridge University Press.

Eisenberg, N., Carlo, G., Murphy, B., \& Court, P. (1995). Prosocial Development in Late Adolescence: A Longitudinal Study. Child Development, 66, 11791197.

Gommans, R., Sandstrom, M. J., Stevens, G. W. J. M., Bogt, T. F. M., \& Cillessen, A. H. N. (2017). Popularity, Likeability, and Peer Conformity: Four Field Experiments. Journal of Experimental Social Psychology, 73, 279-289.

Haryati, T. D. (2013). Kematangan Emosi, Religiusitas, dan Perilaku Prososial Perawat di Rumah Sakit. Jurnal Psikologi Indonesia, 2(2), 162-172.

Lestari, K. A. \& Fauziah, N. (2016). Hubungan antara Konformitas dengan Motivasi Belajar pada Siswa di SMA Muhammadiyah Kudus. Jurnal Empati, 5(4), 717-720.

Santrock, J.W.. (2012). Life Span Development: Perkembangan Masa Hidup Jilid 1 Edisi ke-13 (Benedictine Widyasinta \& Novietha I. Sallama, Penerjemah.). Jakarta : Erlangga.

Saroglou, V. (2006). Religion's Role in Prosocial Behavior: Myth or Reality?. Psychology of Religion Newsletter-AP Division 36, 31(2), 1-16. 
Saroglou, V., Pichon, I., Trompette, L., Verschueren, M., \& Dernelle, R. (2005). Prosocial Behavioi and Religion: New Evidance Based on Projective Measures and Peer Ratings. Journal for the Scientific Study of Religion, 44, 323-348.

Sears, D. O., Peplau, L. A., \& Taylor, S. E. (2009). Psikologi Sosial Edisi Kedua Belas (Wibowo, Penerjemah.). Jakarta: Kencana Prenada Media Group.

Situmorang, F. M. (2014). Busway dalam Renungan. Diakses tanggal 06 April 2017 di http://fransmateusbah.wordpress.com/2014/01/06/buswaydalam-renungan/.

Stamatoulakis, K. K. (2013). Religiosity and Prosociality. Procedia, Social and Behavioral Sciences, 82, 830-834.

Zhixu, Y., Xinyuan, F., Xiaoxia, Y., \& Yichen, L. (2017). Longitudinal relations between adolescents' materialisme and prosocial behavior toward family, friends, and strangers. Journal of Adolescence, 62, 162-170. 